\title{
Od Robinsona do Neli Małej Reporterki. Recykling dziecięcego marzenia o podróży i przygodzie
}

\begin{abstract}
Abstrakt:
Celem artykułu jest przyjrzenie się modyfikacji gatunku powieści podróżniczo-przygodowej w polskiej literaturze dziecięcej i młodzieżowej od XIX do XXI wieku. W centrum rozważań znajdują się XXI-wieczne realizacje gatunku, a ich analiza dokonana została na przykładzie serii o Neli Małej Reporterce (2014- ), wydawanej na licencji National Geographic Society. W artykule wykorzystano narzędzia z zakresu studiów postkolonialnych, odwołano się także do elementów badań socjologicznych nad zjawiskiem masowej turystyki zarówno dorosłych, jak i dzieci, poddając krytyce niektóre zjawiska prezentowane w analizowanej serii i wpisując je w kontekst kultury popularnej w jej umasowionym wydaniu.
\end{abstract}

Słowa kluczowe:

literatura dziecięca i młodzieżowa, masowa turystyka, Nela Mała Reporterka, powieść podróżniczo-przygodowa, reportaż podróżniczy, studia postkolonialne

\section{From Robinson to Nela the Young Reporter: Recycling} a Children's Dream of Travel and Adventure

\section{Abstract:}

The article aims to examine the modifications of the travel and adventure novel genre in Polish children's and young adult literature from the $19^{\text {th }}$ to the $21^{\text {st }}$ century. At the centre of consideration are the $21^{\text {st }}$-century realisations, and their analysis was made on the example of a series about Nela the Young Reporter (2014-Present), published under the license of the National Geographic Society. In the paper, the author uses the tools of postcolonial studies and elements of sociological research on the phenomenon of mass tourism in the context of both adults and children. Several aspects of the analysed series are criticised and framed within the scope of popular culture in its mass variant.

Key words:

children's and young adult literature, mass tourism, Nela the Young Reporter, travel and adventure novel, travel reportage, postcolonial studies

* Ewelina Rąbkowska - mgr, przygotowuje rozprawę doktorską w Instytucie Literatury Polskiej Wydziału Polonistyki na Uniwersytecie Warszawskim dotyczącą kulturowych obrazów zwierząt w polskiej literaturze dla dzieci i młodzieży w perspektywie animal studies. Kieruje Muzeum Książki Dziecięcej w Warszawie. Kontakt: ewelina.rabkowska@365.koszykowa.pl. 
M asowa wyobraźnia dzieci dotycząca swobodnego podróżowania i indywidualnej przygody pozostawała w silnym związku z powieścią podróżniczo-przygodową w każdej fazie rozwoju tego gatunku ${ }^{1}$. Mogła to być podróż daleka, zamorska, jak w Życiu i zadziwiajacych przypadkach Robinsona Kruzoe, marynarza z Yorku Daniela Defoe (1719/1997) albo w Sienkiewiczowskiej (1911/1996) realizacji gatunku, czyli W pustyni $i w$ puszczy. Bywało też tak, że podróże były bliskie, lokalne, jak w wielu przeróbkach tekstu Defoe, tzw. robinsonadach, by wymienić Robinsona szwajcarskiego P. J. Stahla (1864/1909), oraz realizacjach PRL-owskich, m.in. autorstwa Adama Bahdaja (1964/1997 Podróż za jeden uśmiech; 1979 - Telemach $w$ dżinsach; 1982 - Gdzie twój dom, Telemachu?).

Przypadki Robinsona Kruzoe były - według Ryszarda Waksmunda (1987) - pierwszą książką, która poruszyła masową wyobraźnią dzieci, rzutując na całą przyszłą beletrystykę dla młodych czytelników, gdyż dostarczała uczuć kompensacyjnych jako „historia o nieposłuszeństwie względem rodziców” (s. 83). Opowieść o przygodach Robinsona - wykazuje Waksmund - stała się trwałym elementem dziecięcej podkultury, chętnie odtwarzanym w rozlicznych zabawach, których punktem wyjścia była samotna ucieczka w nieznane miejsce (s. 81). Badacz pisze o tej powieści-kosmosie, że tworzy ona mit Robinsona, porównywalny z mitami Don Kichota czy Don Juana (s. 84). Widziany tu świat pozbawiony jest dawnych mitów i fascynacji, za to podporządkowany nadrzędnej idei wpisanej w utwór, mówiącej o przyrodniczej „edukacji od podstaw" (s. 120). W jej ramach świat roślin i zwierząt stanowi model poznania przez doświadczenie. Bohater tekstu uznany zostaje za wzorzec człowieka²: żyje on zgodnie z naturą, ma bowiem tylko tyle, ile jest mu potrzebne, nie chce więcej - i to warunkuje jego szczęście; nie boi się natury, a wręcz panuje nad nią dzięki pracy swych rąk.

Powieść Defoe swą popularnością ustępować ma jedynie Biblii; była wielokrotnie opracowywana, tłumaczona i dostosowywana do dziecięcego czytelnika. Stała się także kanwą do pisania powieści według autorskich pomysłów. Bohater robinsonady odbywa swą podróż odizolowany od cywilizacji i zmuszony jest do organizowania swojego życia na nowym terenie, w trudnych

1 Źródła historyczne poświadczają, że pierwsze zbiorowe marzenie o dalekich wyprawach bez udziału dorosłych dotyczyło chłopców i dziewcząt, którzy uczestniczyli w dziecięcych krucjatach organizowanych w średniowieczu do Jerozolimy (Szumowski, 1988, s. 137-139).

2 Genewski filozof Jean-Jacques Rousseau (1762/1995) w słynnym traktacie pedagogicznym Emil, czyli o wychowaniu zalecał tylko tę jedną książkę tytułowemu bohaterowi do ukończenia przezeń trzynastego roku życia. 
warunkach (Skotnicka, 2002, s. 340-341). W Polsce bardzo wcześnie sławę zdobyły np. opracowanie Przypadków Robinsona przez Joachima Heinricha Campego (1780/1847) oraz wspomniany już Robinson szwajcarski. Niedługo potem zaczęły pojawiać się rodzime opracowania i przeróbki, takie jak Przypadki Robinsona Kruzoe podług najnowszych źródeł Władysława Ludwika Anczyca (1868/1899) czy też Przygody młodzieńca, czyli Robinson polski Adolfa Dygasińskiego (1892/1949). W wieku XX na rodzimym rynku ukazały się też m.in. przekład drugiej części przygód Robinsona (autorstwa Janiny Zawiszy-Krasuckiej) pt. Robinson Kruzoe w podróży naokoło świata (Defoe, 1719/1934) oraz znana adaptacja autorstwa Stanisława Stampf'la (1958/1992), która wpisana została na listę lektur szkolnych.

Uważana za robinsonadę (Ruszała, 1986) powieść Henryka Sienkiewicza (1911/1966) W pustyni i w puszczy, podobnie jak jej angielska inspiracja, zyskała ogromną popularność, nie tylko w Polsce (Ruszała, 1991), lecz także za granicą (Staniów, 2007). Jednak na przełomie wieków podniosły się głosy krytycznie odczytujące opowieść o dwojgu białych chrześcijańskich dzieciach z Europy wcielających w życie imperialne marzenie o podboju Afryki (Błoński, 1960/2002; Kosowska, 1998; Mazan, 1990; Turaj-Kalińska, 2001). Wzrastająca wrażliwość postkolonialna sprawia, że powieść postrzegana jest dziś przez wielu czytelników jako rasistowska. W istocie, przedstawia ona stereotypowy obraz mieszkańców Afryki z perspektywy białego człowieka, a odczytanie postkolonialne „wyprzedza” w tym przypadku lekturę historyczną utworu. Niemniej jednak niegdysiejsza popularność Sienkiewiczowskiej powieści może oznaczać, że przez wiele lat odpowiadała ona na ciągle żywe marzenie młodych ludzi o dalekiej samodzielnej podróży. Jako próby „rehabilitacji” tej lektury czy utrzymania jej w czytelniczym obiegu można postrzegać takie utwory jak zbiór reportaży podróżniczych Śladami Stasia i Nel oraz Z Panem Biegankiem w Abisynii Mariana Brandysa (1961-1962/1995) czy powieść Staś i Nel. Zaginiony klejnot Indii Leszka K. Talki (2014), kontynuację przygód Sienkiewiczowskich bohaterów wzbogaconą o krytykę oryginału, uwzględniającą nowoczesne prądy, takie jak feminizm, postkolonializm czy animal studies.

W PRL-u dziecięce marzenie o przygodzie i samodzielnej podróży przybrało formę narastającego po wojnie problemu: włóczęgostwa dzieci zwanego "gigantem”. Dlatego też np. w twórczości Bahdaja fantazje o niekontrolowanych peregrynacjach młodych ludzi zostały skanalizowane $\mathrm{w}$ formie podróży krajoznawczej, czyli edukacyjnej (Rąbkowska, 2016), a "gigant” został skarcony w takich powieściach tego autora, jak wspomniane części dylogii o Telemachu czy też Podróż za jeden uśmiech. Pozytywny, aprobowany wzorzec podróżowania niedorosłych w powieściach Bahdaja to zorganizowana wycieczka, kolonie, 
wakacje na wsi - zawsze pod nadzorem dorosłego. W czasach współczesnych w krajach Zachodu samodzielne przemieszczanie się dzieci jest natomiast obwarowane prawnymi obostrzeniami. Chłopcy i dziewczęta do lat dwunastu nie mogą sami poruszać się nawet w przestrzeni rodzinnego miasta. Mimo to dziecięce marzenie o samodzielnej dalekiej podróży znowu zostaje zagospodarowane przez literaturę dla młodych odbiorców, tym razem jednak jest przefiltrowane i ukształtowane przez kulturę popularną, a przyjmuje formę dziecięcego reportażu podróżniczego. Kamila Rogowicz (2018) słusznie zauważa, że reportaż ów czerpie właśnie z wcześniejszej „bogatej tradycji podróżniczo-przygodowej literatury dla dzieci i młodzieży” (s. 326). Ta nowa forma jest „multimedialna” (s. 326) i kreuje postać „trawelebryty” (s. 327) jako dziecięcego bohatera reportażu. Przedstawia się tu marzenie do złudzenia przypominające podróże dorosłych, a raczej fantazje o podróżowaniu, które zostały utowarowione i są sprzedawane jako produkt, pakiet praktyk i rytuałów dla bogatych społeczeństw Zachodu. Nie wiemy zatem, jakie są realne marzenia oraz potrzeby najmłodszych, wiemy natomiast, jak niemal na naszych oczach te marzenia są konstruowane i sprzedawane dzieciom, przyszłym klientom biur podróży. Zwiedzanie świata $\mathrm{w}$ wydaniu dziecięcego reportażu podróżniczego miałoby zatem wymiar konsumpcyjny.

W Polsce książki realizujące tę fantazję, które zyskały największą popularność i związane są z nowoczesnym, globalnym podróżowaniem, to seria o Neli Małej Reporterce. Mała Reporterka to pseudonim bohaterki książek, które wydają się tekstami własnymi dziecka (narracja jest pierwszoosobowa) ${ }^{3}$. Na serię składają się następujące części (wydane w Warszawie przez spółkę Burda na licencji udzielonej przez National Geographic Society) ${ }^{4}$ :

- 10 niesamowitych przygód Neli (2014a);

- Nela na 3 kontynentach. Podróże w nieznane (2014b);

- Nela i tajemnice świata (2015a);

- Nela na tropie przygód (2015b);

- Nela na kole podbiegunowym (2016a);

- Śladami Neli przez dżungle, morza i oceany (2016c);

- Nela i polarne zwierzęta (2017a);

- Nela i skarby Karaibów (2017b);

- Nela i tajemnice oceanów (2017c);

3 O tym, że w rzeczywistości nie mogą to być teksty dziecka, przekonuje Grzegorz Leszczyński, dowodząc, że „dziecko nie potrafi poruszać się na tylu poziomach narracji” (Pilip, 2018, s. 5).

4 Stan na czerwiec 2019 roku. 
- Nela i sekrety dalekich lądów (2018a);

- Nela i wyprawa do serca dżungli (2018b);

- Nela na wyspie rajskich ptaków (2018c);

- Nela, zapiski zoologa (2018d);

- Nela i kierunek Antarktyda (2019).

Ponadto cykl wzbogacają dodatkowe książki, np. kalendarz pt. Przygodnik 2016/2017. 365 dni dookoła świata $z$ Nela (2016b) oraz ćwiczeniówka Zabawy $z$ Nela. Tajemnice i zagadki (2016d). Seria podbiła rynek wydawniczy: np. w 2016 roku aż sześć tytułów znalazło się na liście TOP 10 w sieci sklepów Empik, na organizowane z dziewczynką spotkania autorskie przychodziło wówczas każdorazowo ok. 1500 osób, a jedna z książek została wpisana na listę lektur szkolnych (Druś, 2016). Na rynku seria ta współistnieje z programem telewizyjnym Nela Mała Reporterka emitowanym w odcinkach na kanale TVP ABC (b.a., 2013- ).

Główne, fabularne części serii książek korzystają co prawda ze schematu powieści podróżniczo-przygodowej, a także reportażu, ale owe gatunki są tu przekształcane przez kulturę popularną w jej odmianie umasowionej. W związku z tym forma podawcza jest maksymalnie uproszczona. Zamiast obszernej powieści czy szczegółowego reportażu utwory stanowią serię krótkich opowiadań uzupełnianych materiałem fotograficznym lub infograficznym. Objętość tekstu jest równoważna powierzchni form graficznych albo mniejsza od nich: mowa głównie o zdjęciach, ale i rysunkach oraz schematach. Od czwartego tomu serii w książkach o Neli zamieszczane są kody QR, dzięki którym opowieści zyskują charakter intermedialny. Wyraźna jest dążność już nie tylko autorki tekstu, lecz także wydawcy czy redaktora inicjującego, a więc projektantów tego produktu książkowego, do uzyskania efektu „pełnego zanurzenia” (Szybowicz, 2018) zakładanego odbiorcy (konsumenta) w opowieści. Narracja jest przeplatana fragmentami edukacyjnymi, wiadomościami dotyczącymi odwiedzanych miejsc, danymi związanymi z gatunkami fauny i flory napotykanymi przez bohaterkę.

Książki o Neli nawiązują też bardzo wyraźnie do schematu robinsonady, w tym także - co ciekawe - do jej realizacji autorstwa Sienkiewicza. Samo imię dziewczynki budzi skojarzenia z Nelly Rawlison, ośmioletnią bohaterką wykreowaną przez noblistę. Tak jak Nel, Mała Reporterka w pierwszym tomie ma osiem lat. Jest drobną blondynką o niebieskich oczach, więc jej charakterystyka odpowiada wyglądowi postaci u Sienkiewicza, tak silnie utrwalonemu w naszej kulturze za sprawą powieści oraz jej adaptacji filmowych. Już w pierwszym tomie „autorstwa” Neli Małej Reporterki (2014a) 
występują liczne nawiązania do motywów kojarzonych z przygodami znanymi z W pustyni i w puszczy. W rozdziale początkowym tego tomu, zatytułowanym Mieć słonia na jeden dzień, dziewczynka jeździ na grzbiecie tytułowego zwierzęcia podobnie jak Nel i rozmawia z nim, co jest bardzo czytelnym nawiązaniem. Słoń jest dostojny i rozważny - tak jak Sienkiewiczowski kolos - oraz nie robi dziewczynce krzywdy, a jazda na nim jest wspaniałą przygodą. Eliza Szybowicz (2018), porównując ze sobą te dwie dziewczęce postaci, pisze, że podczas gdy Nel tkwiła w samym centrum patriarchalnego świata i nie próbowała z nim walczyć, Nela Mała Reporterka jest postacią samodzielną i sprawczą. Zestawianie tych bohaterek jako kontrastowych wobec siebie, na „korzyść” tej współczesnej, zdaje się jednak na wyrost, a przekonują nas o tym rozważania na temat pozornej emancypacji, np. dotyczące zjawiska zwanego fake feminism (Kostecka, 2019). Pierwowzór Sienkiewiczowski jest zresztą w serii o Neli dość swobodnie potraktowany i jawi się jako zestaw toposów literackich. Oba te teksty nawiązują do wizerunku dziecka-kolonizatora albo - szerzej - do mitu małego Robinsona, w łagodnym, empatycznym wydaniu dziewczęcym, a nie w tym agresywnym, związanym z podbojem - chłopięcym ${ }^{5}$. Nela Mała Reporterka jest ciekawa świata, podobnie jak Nel, ale w przeciwieństwie do swej Sienkiewiczowskiej koleżanki zdaje się nie bać natury i nie okazywać wobec niej słabości. Pozorne panowanie współczesnej bohaterki nad światem przyrody wyraża się w ogromnej wiedzy encyklopedycznej, jaką dysponuje i prezentuje czytelnikowi.

Forma powieści podróżniczo-przygodowej, mogąca uchodzić za staroświecką, została tu więc poddana recyklingowi ${ }^{6}$ oraz wymieszana $\mathrm{z}$ elementami reportażowymi, tworząc coś na kształt narracyjno-edukacyjnej pulpy, formy sylwicznej. Mamy do czynienia z dziecięcym asamblażem, adaptacją obydwu gatunków. Właśnie owo połączenie „zmyślenia” powieści i „prawdy” reportażu, a także napięcie między Nelą jako bohaterką literacką a Nelą jako prawdziwym dzieckiem i jednocześnie autorką tekstów, paradoksalnie sprawiają, że wychodzą na jaw tendencje do cenzury, tabuizacji, a nawet ideologizacji, na które literatura dla dzieci z racji swego statusu była i jest bardzo podatna.

5 Na rynku ukazał się „chłopięcy” odpowiednik książek o Neli, którego wydanie nawiązuje do nich szatą graficzną i formą, a także ogólną koncepcją produktu - jest to Dziennik łowcy przygód. Extremalne Borneo Szymona Radzimierskiego (2016). Już sam tytuł sugeruje, że zdobywanie przestrzeni przez chłopca jest rozumiane jako odważniejsza i niebezpieczniejsza przygoda. Książka zdobyła popularność i doczekała się kontynuacji (Radzimierski, 2018).

6 Użycie pojęcia recyklingu jest tu uzasadnione jego powiązaniem ze specyfiką ponowoczesności, którą opisał Zygmunt Bauman (2004). 
Ułuda opowieści o Neli jest zatem tym bardziej wyraźna, że podawana jako „prawda”, a sama dziewczynka, przemieniona w autorkę i bohaterkę swych narracji, oddala się od tego, kim naprawdę jest (nawet jej imię, Nela, jawi się jako przemyślany element produktu książkowego, a nawet całej marki). Książki o Neli, stwarzając pozory ponowoczesności i mając wszelkie jej atrybuty, są zatem bardzo konserwatywne w swej wymowie?

Mechanizmy popkultury powodują, że nawet treści niegdyś rewolucyjne zostają przez nią wchłonięte i utowarowione na użytek masowego odbiorcy ${ }^{8}$. Przedmiotem utowarowienia $\mathrm{w}$ serii o Neli jest dziecięce marzenie o wolnym i samodzielnym poznawaniu świata, wiążącym się z konceptem ponowoczesnej, globalnej podróży. Dziecko jako bohater literacki emancypuje się w sposób pozorny. Chociaż realizuje swe marzenie o podróżach, to ich specyfika w rzeczywistości pozatekstowej jest związana z typem podróżowania osiągalnym tylko dla dorosłych (i to procentowo nielicznych, jeśli wziąć pod uwagę statystyki). Podróż dziewczynki do ponad dwudziestu krajów na świecie kreowana jest $\mathrm{w}$ tekście jako wyprawa samodzielna, czyli sugeruje się upodmiotowienie i sprawczość dziecka, co jest wyznacznikiem robinsonady i umotywowane było w tekstach wcześniejszych poprzez element ucieczki/porwania/zagubienia. Tutaj okazuje się to tylko iluzją - wiemy, że Nela w rzeczywistości podróżuje z rodzicami. Słusznie twierdzi zatem Grzegorz Leszczyński (Pilip, 2018, s. 5-6), że fenomen omawianej serii jest bardziej socjologiczny niż literacki, korzysta $\mathrm{z}$ napięcia między dziecięcymi marzeniami a ich realnym statusem $\mathrm{w}$ społeczeństwie - nie tylko polskim, lecz także całego Zachodu. W świetle współczesnych dyskursów, które widzą ponowoczesną podróż jako towar przemysłu turystycznego, postulowany w serii o Neli typ wędrówki skłania ku krytycznym odczytaniom wpisanym w konteksty etyczne, postkolonialne. Podobnie jak w tekstach Defoe i Sienkiewicza, kolejny raz powtarzany jest schemat wyprawy białego podróżnika z Europy do odległych lądów.

Jennie Dielemans (2011) w Witajcie w raju. Reportażach o przemyśle turystycznym opisuje ponowoczesne praktyki łączące się z utowarowieniem przez przemysł turystyczny ludzkiej ciekawości związanej z odwiedzaniem nieznanych miejsc. Podróż coraz częściej bywa reklamowana jako potrzeba „wyrwania się" na chwilę ze swojej rzeczywistości w celu przeżycia przygody czy też odpoczynku. Jak stwierdza autorka (s. 8-10), a także Bauman (2011/2012),

7 To samo zauważa Peter Hunt (2008, s. 80) w odniesieniu do serii o Harrym Potterze.

8 Tak stało się np. z rewolucją obyczajową dzieci kwiatów; dziś jej hasła, takie jak np. ekologiczny tryb życia czy dieta bezmięsna, sprzedawane są pod postacią towarów (specjalna ekologiczna żywność i wegańskie produkty, książki, sprzęt domowy). 
socjolog ponowoczesności, tak ujęta podróż niewiele różni się od narkotyku, którym podobnie jak innymi używkami ludzie próbują leczyć swe deficyty psychiczne związane z życiem w ponowoczesnym społeczeństwie. Turystyka realizowana obecnie przez wielu ludzi lotami czarterowymi jest oceniana przez autorkę jako niemoralna w dobie kryzysu ekologicznego. Demaskując mechanizmy społeczne oraz psychologiczne, które za takimi podróżami stoją, reportażystka wyraża postulat etyczny, aby je powstrzymać .

Tymczasem seria o Neli realizuje właśnie wspomniany typ krytykowanego przez Baumana i Dielemans ponowoczesnego podróżowania, turystyki globalnej, kreując masowe marzenia dzieci na wzór towaru turystycznego, który jest sprzedawany dorosłym. Jego wyznaczniki to:

- intensywność (Nela zmienia kolejne miejsca pobytu bardzo szybko i wielokrotnie w obrębie jednego tomu);

- podróż samolotem do odległych miejsc (wyprawy Neli nie są lokalne, a obejmują cały świat - powstaje iluzja dostępności i łatwości takiego podróżowania);

- pobieżność poznania danego kraju będąca efektem intensywności zwiedzania (Nela w każdym kraju odwiedza od jednej do kilku atrakcji przygotowanych specjalnie dla turystów; w każdym kraju widzi to samo, co wszyscy turyści z Europy);

- przewidywalność destynacji (w przemyśle turystycznym pewne kraje/ regiony muszą zaistnieć jako destynacja, zanim staną się atrakcyjne i osiągalne dla turystów; w praktyce oznacza to, że wolność wyboru destynacji nie istnieje);

- tabuizacja niebezpieczeństwa (w książkach mamy wskazówki na temat tego, co zapakować i jak się ubrać, ale aspekt chociażby zagrożenia zdrowia jest nieobecny; biura podróży w podobny sposób tabuizują ryzyko związane z wyjazdem).

Negatywny aspekt globalnych podróży masowych to - poza zanieczyszczeniem środowiska przez przemysł lotniczy, który nie byłby rozwinięty na taką skalę, gdyby nie turystyka - przemijające mody na kolejne destynacje. Jako że podróż jest towarem - argumentuje autorka Witajcie $w$ raju (Dielemans, 2011) - kraj, który zostanie wypromowany jako cel podróży, uzależnia się od turystów, szczególnie jeśli dotychczas był to biedny rolniczy

9 Podobne spojrzenie na ponowoczesne podróżowanie ujawnia Anna Wieczorkiewicz (2008) w Apetycie turysty. O doświadczaniu świata w podróży. Podróż staje się formą „zachłanności”, „zjadania świata” (Pilip, 2018, s. 6). 
teren. Zyski z turystyki są tak wysokie, że miejscowi się przekwalifikowują, porzucając tradycyjne zajęcia. Masa turystów i idąca za nimi infrastruktura doprowadzają do wypierania miejscowych z ich terenów (główną przyczyną są ceny nieruchomości) oraz degradacji środowiska naturalnego. Od tej chwili autochtoni są zupełnie zależni od koniunktury turystycznej. Procesy globalizacyjne sprawiają, że ludność miejscowa w większości nie posiada wielkich hoteli - te należą do kapitału zagranicznego. Rdzenni mieszkańcy zajmują się drobnym rękodziełem, oferują miejscowe produkty żywnościowe czy pomniejsze usługi. Najbardziej dramatyczna sytuacja ma miejsce w Tajlandii, która słynie z seksualnej turystyki, w tym także z prostytucji dziecięcej (s. 30-43).

Krytyka tego nieetycznego i nieekologicznego aspektu podróżowania jest nieobecna w serii o Neli. Książki ukazują miejscowych w roli przewodników, pomocników czy atrakcji turystycznej („tubylców”). Nawet jeśli pojawia się komentarz dotyczący ich trudnej sytuacji (np. braku powszechnej edukacji dla dzieci czy głodu), to jest on naiwny i wygłaszany z pozycji wyższości:

W Etiopii mało dzieci chodzi do szkoły, więc nie wiedzą one wielu rzeczy. Niektóre nie potrafią nawet pisać i czytać! A kiedy już dorosną, nie wiedzą, jak nawadniać pola, żeby w porze suchej wyrosły im rośliny, i głodują. Nie wiedzą też, jak dbać o zwierzęta, żeby nie chorowały i nie miały pasoży tów. Dlatego nauka jest bardzo ważna (Nela Mała Reporterka, 2014b, s. 57-58).

Zresztą wniknięcie w sytuację miejscowych jest w tym kontekście niemożliwe, są oni bowiem ukazani bardzo stereotypowo. Ich ubóstwo, prostota życia, zajmowanie się rękodziełem zobrazowane są w sposób wyidealizowany, bez ujawnienia właściwych tego przyczyn: globalizacji, biedy, wyniszczenia gospodarki danego kraju, nierówności społecznych. Przykłady znajdziemy w spotkaniach Neli z kobietami wyławiającymi wodorosty dla zachodniego przemysłu kosmetycznego (Nela Mała Reporterka, 2014a, s. 46), rolnikami uprawiającymi ryż (s. 60) czy pracownikami kopalni siarki (s. 78). Często najniżej płatne prace w turystyce zarezerwowane są dla cudzoziemców o nieuregulowanym statusie. Nierzadko ludzie ci pracują za płace minimalne, bez ubezpieczenia emerytalnego, które w krajach Zachodu jest uznawane za standard. Warto też zwrócić uwagę na stereotypowość dołączonych do książki fotografii. Tubylcy są zajęci pracą, zawsze uśmiechnięci i pomocni wobec bohaterki. Dielemans (2011, s. 62, 79) zauważa, że jest to uśmiech wymuszony oraz że podczas takich podróży płacimy za to, co powstało pod dyktando naszych własnych projekcji. Często eksponowany jest też odmienny wygląd ludzi, szczególnie sposoby zdobienia 
ciał, jak w przypadku kobiet z plemienia Mursi (Nela Mała Reporterka, 2015b, s. 114) czy z plemienia Karenów (Nela Mała Reporterka, 2015a, s. 160-175), bez komentarza odnoszącego się do kwestii etyczności deformowania w ten sposób kobiecych ciał.

Opisy napotkanych ludzi, szczególnie rówieśników Neli, są również bardzo stereotypowe. Oto jak obrazowane są dzieci etiopskie: „Popatrzyłam na dzieci, które stanęły w rzędzie obok swojej mamy. Muchy siadały im na buziach i wchodziły do oczu. Ale te dzieci nawet się od nich nie odganiały! [...] My mamy odruch odganiania się od much, prawda?” (Nela Mała Reporterka, 2014b, s. 57). Opis kończy się podarowaniem przez bohaterkę plastykowych koralików etiopskim dzieciom. Książka promuje zdecydowanie tradycjonalistyczną wizję świata, w ramach której brakuje świadomości procesów globalizacyjnych powodujących nierówności między poszczególnymi krajami, a nawet kontynentami. Ponadto wpisane w tekst założenie o edukacyjnej funkcji podróżowania pozostaje $\mathrm{w}$ istocie iluzją. Poznanie odwiedzanych miejsc jest niemożliwe - chociaż są czynione pewne obserwacje co do zachowania tubylców, komentarz edukacyjny wyjaśniający prawidłowości czy przyczyny konkretnych zjawisk to nic innego jak wiedza encyklopedyczna "przywieziona w plecaku" przez dziecko z Europy.

W czasach globalnej wioski dalekie kraje, takie jak Tajlandia czy Zanzibar, nie są dzieciom zupełnie obce. Widzą je w telewizji. Podróż stała się towarem, a dalekie wyprawy to moda i snobizm, finansowo dostępne dla promila ludzkości. Sama idea takiej podróży jest przedmiotem sprzedaży (w postaci książek lub reportaży prasowych). Turystyka globalna jest wyniszczająca dla środowiska i - na dłuższą metę - także dla lokalnej gospodarki. Do masowej wyobraźni ten dyskurs ekologiczny i etyczny jednak nie dociera, a jeśli dociera, jest popkulturowo przekształcony i również zmieniony w modę i snobizm, a zatem gotowy do sprzedaży (por. podróże do „nieskażonych” terenów odbywane przez tzw. backpackersów). Kolejny raz potwierdza się to, że forma opowieści podróżniczo-przygodowej najlepiej odpowiada na dziecięce masowe marzenie o podróżowaniu „tak jak dorosły”, marzenie o samodzielności, ucieczce od rodziców i zdobywaniu nowej przestrzeni. Fabuły te stwarzają zatem iluzję takiej podróży - dawniej służyło to celom edukacyjnym i rozrywkowym, a w ponowoczesnej realizacji, w połączeniu z formą reportażową, służy także wyprodukowaniu i sprzedaniu atrakcyjnego dla masowych gustów towaru.

Podsumowując, seria bestsellerowych książek o Neli Małej Reporterce jest ponowoczesną, sylwiczną formą gatunkową, podyktowaną masową odmianą kultury popularnej, której wyznacznikami są: produkt totalny, 
konwergencja mediów, maksymalne uproszczenie odbioru (Leszczyński, Zając, 2013). Elementy powieści podróżniczo-przygodowej zostały w omawianym przypadku poddane recyklingowi: to, co mogło być uznane za staroświeckie, „przemielono” nie do poznania i połączono z reportażem, postrzeganym jako nowocześniejszy. Przy czym ów recykling objął głównie formę opowieści, wpływając niemal wyłącznie na ostateczny kształt książki jako produktu rynkowego. To, co stanowi jej treść, pozostaje w istocie niezmienione: prawdziwe dziecko - ze swymi cechami charakteru, indywidualnością, pochodzeniem i refleksjami - ukryte zostało za zasłoną silnie skonwencjonalizowanej za sprawą Sienkiewiczowskich wzorców bohaterki dziewczęcej. Jej samodzielność i sprawczość to tylko ułuda czy też konstrukty, puste gesty. Podobnie doświadczenie świata, poznawanie go, także relacja z Innym w obcych krainach - przekazane zostały w formie opisów i sądów Neli. Jest ona mediatorem bardzo tradycjonalistycznego spojrzenia na inne kultury, które jednak w książce, w przeciwieństwie do formy narracji powieściowej, nie zostało uznane za „staroświeckie”. Można zakładać, że utwory o Neli, będąc przede wszystkim produktami na sprzedaż, schlebiają popkulturowym gustom i masowej wyobraźni, być może skrzętnie wcześniej zbadanym metodą statystyczną. Dowodzić tego może drugoosobowa forma zwrotu do czytelnika, starannie i intensywnie wprowadzana przy każdej okazji $\mathrm{w}$ toku narracji, podtrzymująca także iluzję wspólnego podróżowania z Nelą:

- Pakuj się i ruszaj ze mną na fantastyczną podwodną przygodę! (Nela Mała Reporterka, 2017c, s. 10).

- Cześć, dziś przeżyjemy razem naprawdę, naprawdę niesamowitą przygodę (s. 83).

- Jeżeli już wiemy, gdzie mamy jechać, to teraz sprawdźmy kiedy J. Mamy do wyboru: wiosnę, lato, jesień i zimę. Jaką porę roku byś wybrał? (Nela Mała Reporterka, 2017a, s. 100).

Jest to forma, która została zaimplementowana do tej publikacji w wyniku zaleceń redakcji tekstów reklamowych (zajmującej się copywritingiem i public relations). Bezpośredni zwrot adresata do nadawcy, stale podtrzymywany, ma zmniejszyć dystans między nimi. Nawiązanie bliskiego kontaktu z odbiorcą poprzez Nelę zwracającą się wprost do czytających dzieci, dbałość o utrzymanie tej bliskości, to pochodna chwytów marketingowych mających związać klienta z marką, jaką seria o Neli (a także sama Nela Mała Reporterka) przecież jest.

W wiele opowieści o podróżach, kierowanych do dzieci zarówno wczoraj, jak i dziś, nieodmiennie wpisane jest przekonanie o wyższości kultury, której 
przedstawicielem jest ich nadawca. $\mathrm{W}$ omawianej realizacji nie zatrzymały owych tendencji nawet elementy reportażu, który przecież jako gatunek może być wiązany $\mathrm{z}$ dążnością do obiektywnego badania faktów i wniknięcia głęboko w perspektywę ludzi zamieszkujących opisywane miejsca - „[...] reportaż ma być lekcją empatii i otwarcia na inność" (Pilip, 2018, s. 6; por. reportaże Ryszarda Kapuścińskiego, Tadeusza Boya-Żeleńskiego czy Ksawerego Pruszyńskiego). W samej kulturze i literaturze dla dzieci od dawna popularny i wydaje się, że kontrapunktowy wobec modelu Robinsowskiego, jest model Guliwerowski (Podróże do wielu odległych narodów świata przez Lemuela Gulliwera, początkowo lekarza okrętowego, a następnie kapitana licznych okrętów autorstwa Jonathana Swifta, 1726/1949). Oto Guliwer, wkraczając do krainy Liliputów, wykazuje się niebywałą wręcz delikatnością, nie chcąc ich skrzywdzić (co ujęte jest w ciekawy koncept zabawy skalą: ogromny - mały). Autor Guliwera, wykorzystując podróżniczo-przygodową fabułę, schlebiając gustom o dalekiej, samotnej podróży, tworzy zarazem satyrę na społeczeństwo Zachodu. W formule przyjętej w książkach o Neli zabrakło miejsca na pogłębioną refleksję o świecie, w którym żyje współczesne polskie dziecko, a surowe osądzające spojrzenie kierowane jest z perspektywy rzekomej wyższości polskiej i - szerzej - europejskiej kultury na protekcjonalnie traktowaną, „uroczą”, lilipucią i bliżej nieokreśloną, a więc ciągle odległą resztę świata. Być może zabrakło tutaj nieco Swiftowskiego dziedzictwa, a także inspiracji dobrą tradycją polskiego reportażu dla dorosłych.

\section{Bibliografia}

Anczyc, W. L. (1899). Przypadki Robinsona Kruzoe podług najnowszych źródeł. Warszawa: Gebethner i Wolff. (wyd. oryg. 1868).

b.a. (2013- ). Nela Mała Reporterka [serial telewizyjny]. Warszawa: TVP 1, TVP ABC. Bahdaj, A. (1997). Podróż za jeden uśmiech. Wrocław: Siedmioróg. (wyd. oryg. 1964).

Bahdaj, A. (1979). Telemach $w$ dżinsach. Warszawa: Krajowa Agencja Wydawnicza.

Bahdaj, A. (1982). Gdzie twój dom, Telemachu?. Warszawa: Krajowa Agencja Wydawnicza.

Bauman, Z. (2004). Życie na przemiat (T. Kunz, tłum.). Warszawa: Wydawnictwo Literackie.

Bauman, Z. (2012). Straty uboczne. Nierówności społeczne w epoce globalizacji (J. Hunia, tłum.). Kraków: Wydawnictwo UJ. (wyd. oryg. 2011).

Błoński, J. (2002, 15 września). Staś i Nel. Tygodnik Powszechny. Pobrane z: http://www. tygodnik.com.pl/numer/277537/blonski-felieton.html?fbclid=IwAR1kvAZrIUEXc Akkir6eeO538dkgxG1rBB8HWMzw6bAseeFF2fS3KNtzUC0. (wyd. oryg. 1960). 
Brandys, M. (1995). Śladami Stasia i Nel; Z panem Biegankiem w Abisynii. Warszawa: Świat Książki. (wyd. oryg. 1961-1962).

Campe, J. H. (1847). Przypadki Robinsona (L. Szyrma, tłum.). Warszawa: Samuel Orgelbrand. (wyd. oryg. 1780).

Defoe, D. (1934). Robinson Kruzoe w podróży naokoło świata (J. Zawisza-Krasucka, tłum.). Warszawa: Księgarnia Popularna. (wyd. oryg. 1719).

Defoe, D. (1997). Przypadki Robinsona Kruzoe (J. Birkenmajer, tłum.). Poznań: Podsiedlik-Raniowski i Spółka. (wyd. oryg. 1719).

Dielemans, J. (2011). Witajcie w raju. Reportaże o przemyśle turystycznym. Wołowiec: Wydawnictwo Czarne.

Druś, A. (2016, 22 grudnia). Polska 11-latka podbiła rynek wydawniczy. Puls Biznesu. Pobrane z: https://www.pb.pl/polska-11-latka-podbila-rynek-wydawniczy-850571.

Dygasiński, A. (1949). Przygody młodzieńca, czyli Robinson polski. Warszawa: Książka i Wiedza. (wyd. oryg. 1892).

Hunt, P. (2008). Literatura dla dzieci a dzieciństwo. W: M. J. Kehily (red.), Wprowadzenie do badań nad dzieciństwem (M. Kościelniak, tłum., s. 61-83). Kraków: WAM.

Kosowska, E. (1998). W pustyni i w puszczy - śladami europocentryzmu. W: L. Ludorowski (red.), W kregu arcydzieł literatury młodzieżowej. Interpretacje-przekłady - adaptacje (s. 47-73). Lublin: Wydawnictwo UMCS .

Kostecka, W. (2019). Nowe wcielenia kobiecości? Atrybuty bohaterek współczesnej fantastyki dziecięcej i młodzieżowej. Prolegomena. W: A. Mik, M. Niewieczerzał, E. Rąbkowska, G. Leszczyński (red.), O czym mówią rzeczy? Świat przedmiotów w literaturze dziecięcej i młodzieżowej (s. 107-131). Warszawa: Wydawnictwo SBP.

Leszczyński, G., Zając, M. (2013). Książka i młody czytelnik: zbliżenia, oddalenia, dialogi. Studia i szkice. Warszawa: Wydawnictwo SBP.

Mazan, L. (1990). Ty znać Nel? Ty słyszeć o Staś?. Przekrój, 2361, 20.

Nela Mała Reporterka. (2014a). 10 niesamowitych przygód Neli. Warszawa: Burda.

Nela Mała Reporterka. (2014b), Nela na 3 kontynentach. Podróże w nieznane. Warszawa: Burda.

Nela Mała Reporterka. (2015a). Nela i tajemnice świata. Warszawa: Burda.

Nela Mała Reporterka. (2015b). Nela na tropie przygód. Warszawa: Burda.

Nela Mała Reporterka. (2016a). Nela na kole podbiegunowym. Warszawa: Burda.

Nela Mała Reporterka. (2016b). Przygodnik 2016/2017. 365 dni dookoła świata z Nela. Warszawa: Burda.

Nela Mała Reporterka. (2016c). Śladami Neli przez dżunglę, morza i oceany. Warszawa: Burda.

Nela Mała Reporterka. (2016d). Zabawy z Nela. Tajemnice i zagadki (K. Granowicz, H. Kosarczyn, oprac.). Warszawa: Burda.

Nela Mała Reporterka. (2017a). Nela i polarne zwierzęta. Warszawa: Burda. 
Nela Mała Reporterka. (2017b). Nela i skarby Karaibów. Warszawa: Burda.

Nela Mała Reporterka. (2017c). Nela i tajemnice oceanów. Warszawa: Burda.

Nela Mała Reporterka. (2018a). Nela i sekrety dalekich lądów. Warszawa: Burda.

Nela Mała Reporterka. (2018b). Nela i wyprawa do serca dżungli. Warszawa: Burda.

Nela Mała Reporterka. (2018c). Nela na wyspie rajskich ptaków. Warszawa: Burda.

Nela Mała Reporterka. (2018d). Nela. Zapiski zoologa. Warszawa: Burda.

Nela Mała Reporterka. (2019). Nela i kierunek Antarktyda. Warszawa: Burda.

Pilip, Ł. (2018). Nela mała turystka. Książki dla dzieci i młodszych dorostych, dod. do Ksiażki. Magazyn do Czytania, 4, 2-7.

Radzimierski, S. (2016). Dziennik łowcy przygód. Extremalne Borneo. Warszawa: Burda.

Radzimierski, S. (2018). Dziennik łowcy przygód. Etiopia: u stóp góry ognia. Warszawa: Burda.

Rąbkowska, E. (2016). Uciekinierzy do „piątej strony świata” w prozie Adama Bahdaja dla dzieci i młodzieży. W: W. Kostecka, M. Skowera (red.), Geografia krain zmyślonych. Wokół kategorii miejsca i przestrzeni w literaturze dziecięcej, młodzieżowej i fantastycznej (s. 197-211). Warszawa: Wydawnictwo SBP.

Rogowicz, K. (2018). Podróż za (nie)jeden uśmiech. Dziecięcy reportaż podróżniczy w literaturze i nowych mediach. W: K. Jędrych, D. Krzyżyk, M. Ochwat, M. Wójcik-Dudek (red.), Przestrzenie spotkania. Tom dedykowany Profesor Ewie Jaskółowej w czterdziestolecie pracy naukowej i dydaktycznej (s. 323-330). Katowice: Wydawnictwo UŚ.

Rousseau, J.-J. (1955). Emil, czyli o wychowaniu (W. Husarski, tłum., J. Legowicz, wst. i kom.). Wrocław: Zakład Narodowy im. Ossolińskich. (wyd. oryg. 1762).

Ruszała, J. (1986). W pustyni i w puszczy Henryka Sienkiewicza w kontekście Robinsona Cruzoe D. Defoe. Polonistyka, 9, 673-680.

Ruszała, J. (1991). Karta z dziejów recepcji W pustyni i w puszczy. Guliwer, 2, 49-54.

Sienkiewicz, H. (1966). W pustyni i w puszczy. Warszawa: PIW. (wyd. oryg. 1911).

Skotnicka, G. (2002). Robinsonada. W: B. Tylicka, G. Leszczyński (red.), Słownik literatury dziecięcej i młodzieżowej (s. 340-341). Wrocław, Warszawa, Kraków: Zakład Narodowy im. Ossolińskich.

Stahl, P. J. (1909). Robinson szwajcarski (J. Chęciński, tłum., S. Barszczewski, oprac. i przyp.). Warszawa, Kraków: Gebethner i Wolff. (wyd. oryg. 1864).

Stampf'l, S. (1992). Robinson Kruzoe według Daniela Defoe. Warszawa: Nasza Księgarnia. (wyd. oryg. 1958).

Staniów, B. (2007). W pustyni i w puszczy Henryka Sienkiewicza - najbardziej znana w świecie polska książka dla dzieci. Świat Książki Dziecięcej, 12 [dod. do Poradnika Bibliotekarza, 12], 1-4.

Swift, J. (1949). Podróże Guliwera (C. Niewiadomska, tłum.). Warszawa: Gebethner i Wolff. 
Szumowski, W. (1988). [Wyprawy krzyżowe dzieci]. W: M. Janion, S. Chwin (red.), Transgresje. Dzieci (t. 1, s. 137-139). Gdańsk: Wydawnictwo Morskie.

Szybowicz, E. (2018, 8 sierpnia). Cudowny świat Neli. Krytyka Polityczna. Pobrane z: https://krytykapolityczna.pl/kultura/czytaj-dalej/eliza-szybowicz-nela-mala-reporterka/.

Talko, L. K. (2014). Staś i Nel. Zaginiony klejnot Indii. Kraków: Znak Emotikon.

Turaj-Kalińska, K. (2001). Mały biały samiec. Dekada Literacka, 11/12, 91-95.

Waksmund, R. (1987). Nie tylko Robinson, czyli o oświeceniowej literaturze dla dzieci i młodzieży. Warszawa: Młodzieżowa Agencja Wydawnicza.

Wieczorkiewicz, A. (2008). Apetyt turysty. O doświadczaniu świata w podróży. Kraków: TAiWPN Universitas. 